\title{
PEMANFAATAN SEKURITISASI ASET DALAM MENDORONG SEKTOR RIIL: ALTERNATIF PEMBIAYAAN UMKM
}

\author{
Wijoyo Santoso \\ Shinta R.I. Soekro \\ Darmansyah \\ Hilde D. Sihaloho ${ }^{1}$
}

\begin{abstract}
This paper analyzes the asset securitization as a source of financing for small and medium scale enterprise. We use field survey and focus group discussion in Jabodetabek, Bandung, Yogyakarta, Denpasar, Medan, and Banjarmasin, covering 149 samples in total. This paper found the banks generally are in excess liquidity condition, therefore face difficulty on obtaining the minimum of Loan to Deposit Ratio (LDR). For this reason, those banks are not interested to sell the SME's loan though they are quite interested on the asset securitization concept. For the banks, the major motive to invest in asset securitization program is a high yield. In addition, they expect this portfolio to increase the LDR. Prior the implementation of this program, this paper underlines the necessity to overcome some obstacles including non-bankable SME's, liquidity and human resource of the banks, and limited information of the asset securitazion program (EBA-UMKM).
\end{abstract}

Keywords: asset securitization, SME's, banking.

JEL Classification: D24, L6, E32

1 Peneliti di Pusat Pendidikan dan Studi Kebanksentralan, Bank Indonesia.Pandangan dalam paper ini merupakan pandangan penulis dan tidak merefleksikan pandangan PPSK atau Bank Indonesia. E-mail: : wijoyo_s@bi.go.id, shinta@bi.go.id, darmansyah@bi.go. id, dan dameria@bi.go.id

Received: April 2014. Accepted for Publication : October 2014 


\section{PENDAHULUAN}

Pemerintah senantiasa mendorong pertumbuhan usaha mikro, kecil dan menengah (UMKM) mengingat UMKM merupakan driving force perekonomian yang dikarenakan UMKM membantu kesejahteraan ekonomi lewat pembangunan dan pertumbuhan, serta merupakan sumber pekerjaan utama bagi masyarakat. Tercatat pada tahun 2010, kontribusi UMKM terhadap PDB sebesar 56,22\%, lebih tinggi dibandingkan dengan kontribusi usaha besar terhadap PDB (43,78\%). Ditinjau dari penyerapan tenaga kerja, sektor UMKM menyerap hampir seluruh tenaga kerja di Indonesia $(97,27 \%$ ) yang sebesar 90,83\% merupakan daya serap usaha mikro. Sementara kontribusi UMKM terhadap total eskpor adalah sebesar 15,81\% (Biro Pusat Statistik, 2010).

Temuan hasil penelitian tahun 2011 mengenai sekuritisasi aset UMKM adalah secara umum seluruh pihak terkait (Bank Umum, BPD, BPR, Investor), berdasarkan hasil survei, memiliki, ketertarikan dan minat yang cukup besar terhadap sekuritisasi atau Efek Beragun Aset (EBA). Namun, pemahaman (awareness) terhadap sekuritisasi masih beragam di antara pihakpihak terkait. Pemahaman investor sangat memadai mengenai aspek sekuritisasi, sementara pemahaman sebagian bank umum dan BPD serta hampir separuh BPR yang disurvei masih kurang bahkan negatif. Sektor UMKM yang potensial untuk dilakukan sekuritisasi adalah sektor keuangan, perdagangan, pertambangan, dan pertanian dalam arti luas. Untuk pelaksanaan sekuritisasi aset UMKM, diperlukan pembenahan atau pembinaan UMKM dari sisi manajemen dan tata laksana dalam rangka meningkatkan kinerja Good Corporate Governance (GCG).

Hasil penelitian tahun 2011 juga menunjukkan bahwa pembiayaan untuk UMKM melalui sekuritisasi aset telah diterapkan oleh beberapa negara, seperti Italia, Korea Selatan, Malaysia, Spanyol, Jepang, dan Jerman. Bank-bank komersial di Jerman sukses dalam menjalankan sekuritisasi atas pinjaman-pinjaman UMKM baik secara individu atau dibantu oleh agen pemerintah, seperti KfW's PROMISE (Promotional Mitterland Loan Securities). Bank of Japan (BOJ) menerapkan kebijakan pembelian SME-related Asset-Backed Securities (ABS) dalam rangka memperbaiki mekanisme transmisi moneter dengan mendiversifikasi risiko di sektor keuangan.

Seperti halnya di negara lain, sekuritisasi aset di Indonesia juga telah dilakukan untuk kredit pemilikan rumah (KPR). Pada tahun 2008, Bank Tabungan Negara (BTN) melakukan sekuritisasi aset properti melalui skema Kontrak Investasi Kolektif Beragun Aset (KIK-EBA) untuk pertama kali dengan tujuan mendorong penurunan suku bunga kredit perumahan rakyat dalam jangka panjang. Total KIK-EBA yang telah dikeluarkan hingga tahun 2010 mencapai Rp1,2 triliun. Bertindak sebagai pengatur (arranger) adalah PT Sarana Multigriya Finansial (SMF).

Hasil penelitian tahun 2011 merekomendasikan untuk dilakukan penelitian lanjutan di tahun 2012 untuk mengetahui secara pasti potensi penerapan sekuritisasi aset UMKM dari aspek kesiapan UMKM, dan minat pihak terkait lainnya yaitu originator, investor, lembaga penjamin. Dengan latar belakang ini, maka penelitian lanjutan tahun 2012 bertujuan untuk: 
a. Mengkonfirmasi hasil penelitian tahun 2011 mengenai minat pihak-pihak terkait khususnya perbankan untuk melakukan sekuritisasi aset UMKM, sebagai bagian dari upaya Bank Indonesia untuk melakukan financial deepening;

b. Menentukan strategi pengembangan pembiayaan sekuritisasi aset dalam membiayai UMKM di Indonesia.

\section{TEORI}

\subsection{Definisi Sekuritisasi Aset}

Dalam Peraturan Pemerintah (PP) Nomor 19 Tahun 2005 disebutkan bahwa sekuritisasi aset adalah transformasi aset yang tidak likuid menjadi likuid dengan cara pembelian aset keuangan dari kreditur asal dan penerbit efek beragun aset (EBA). Sementara Peraturan Bank Indonesia Nomor 7/4/2005 menyebutkan bahwa sekuritisasi aset adalah penerbitan surat berharga oleh penerbit EBA yang didasarkan pada pengalihan aset keuangan dari kreditur asal yang diikuti dengan pembayaran yang berasal dari hasil penjualan efek beragun aset kepada pemodal. Sedangkan Bank for International Settlements mendefinisikan sekuritisasi sebagai "securitization can transform a pool of ordinarily illiquid and risky assets into larger assets that can be more liquid, less risky, and more marketable" [sekuritisasi dapat mentransformasi sekumpulan aset yang tidak likuid dan beresiko menjadi aset yang lebih besar yang lebih likuid, tidak terlalu beresiko dan lebih dapat dijual].

Peraturan Bapepam Nomor IX.K.1 menyebutkan bahwa efek beragun aset (EBA) adalah efek yang diterbitkan oleh kontrak investasi kolektif EBA (KIK-EBA) yang portofolionya terdiri atas aset keuangan berupa tagihan yang timbul dari surat berharga komersial, tagihan kartu kredit, tagihan yang timbul di kemudian hari (future receivables), pemberian kredit termasuk kredit pemilikan rumah atau apartemen, efek bersifat hutang yang dijamin oleh pemerintah, sarana peningkatan kredit (credit enhancement)/arus kas (cash flow enhancement), serta aset keuangan setara dan aset keuangan lain yang berkaitan dengan aset keuangan tersebut. KIK-EBA merupakan kontrak antara manajer investasi (MI) dan bank custodian yang mengikat pemegang EBA. Dalam hal ini MI diberi wewenang untuk mengelola portofolio investasi kolektif dan bank custodian diberi wewenang untuk melaksanakan penitipan kolektif. 


\subsection{Mekanisme Transaksi Sekuritisasi Aset}

Mekanisme Transaksi Efek Beragun Aset (EBA) di Indonesia dapat dilihat pada Diagram 1.

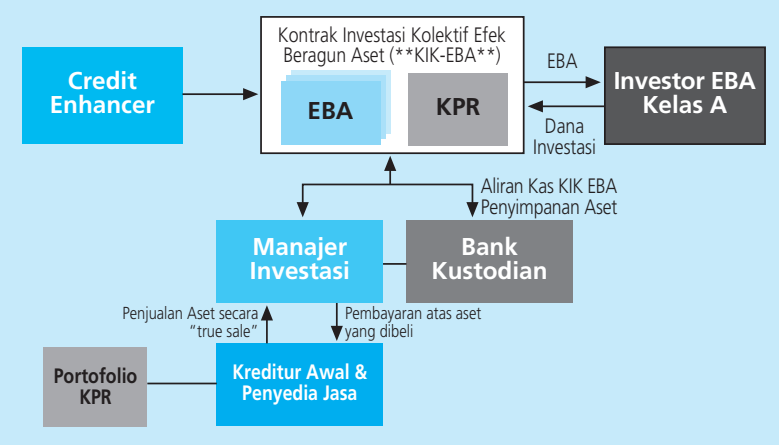

a. Perusahaan (originator) mengalihkan aset keuangannya kepada Ml yang dicatatkan atas nama bank kustodian untuk kepentingan pemegang EBA.

b. Portofolio KIK-EBA yang telah direstrukturisasi oleh MI kemudian diperingkat oleh lembaga pemeringkat (rating agency) dan dapat diberikan sarana peningkatan kredit atau arus kas. Jika dilakukan penawaran umum kepada investor, MI perlu dibantu oleh penjamin emisi efek (underwriter).

c. Penjualan KIK-EBA dapat dilakukan secara terbuka di pasar modal atau secara langsung kepada investor.

d. Arus kas pelunasan EBA dari debitur kepada servicer (bisa dilakukan oleh originator).

Sumber : Bank BTN

\section{Diagram 1. Mekanisme Transaksi Efek Beragun Aset (EBA) di Indonesia}

Penghitungan biaya dan return dalam transaksi sekuritisasi aset dapat dilihat pada Tabel 1.

\begin{tabular}{|c|c|}
\hline \multicolumn{2}{|c|}{$\begin{array}{c}\text { Tabel } 1 \text { Penghitungan Biaya Dan Return Dalam Transaksi } \\
\text { Sekuritisasi Aset }\end{array}$} \\
\hline Ilustrasi Komponen Biaya & Ilustrasi Return \\
\hline 1. Bunga $\left.15 \%{ }^{*}\right)$ & - \\
\hline 2. Return bagi Investor: $11 \%$ *) & - $15 \%-11 \%=4 \%$ \\
\hline 3. Para Penunjang: $0.75 \%{ }^{*}$ ) & - $4 \%-0,75 \%=3,25 \%$ \\
\hline 4. Loss Portofolio: $1 \%{ }^{*}$ ) & - $3,25 \%-1 \%=2,25 \%$ \\
\hline 5. Residual Value: $2,25 \%$ & Revenue bagi originator \\
\hline
\end{tabular}

1. Pembayaran bunga kredit sebesar $15 \%$

2. Pembayaran coupon untuk investor sebesar $11 \%$, masih tersisa $4 \%$

3. Pembayaran fee untuk para penunjang (parties) sebesar $0,75 \%$ sehingga masih tersisa $3,25 \%$

4. Biaya atas penurunan kualitas pool (loss portofolio) sebesar $1 \%$, mengurangi sisa $3,25 \%$ menjadi $2,25 \%$

5. Persentase yang tersisa sebesar $2,25 \%$ merupakan residual value yang pada setiap akhir periode pembayaran (triwulan) menjadi hak pemegang EBA

Penghitungan suku bunga adalah sebagai berikut:

Suku Bunga = return bagi investor + biaya penunjang + loss portofolio + residual value (revenue originator) 


\subsection{Manfaat Sekuritisasi Aset UMKM}

Diagram 2 menjelaskan mengenai manfaat dari penerapan sekuritisasi aset yang diperoleh oleh originator, investor, UMKM dan pemerintah.

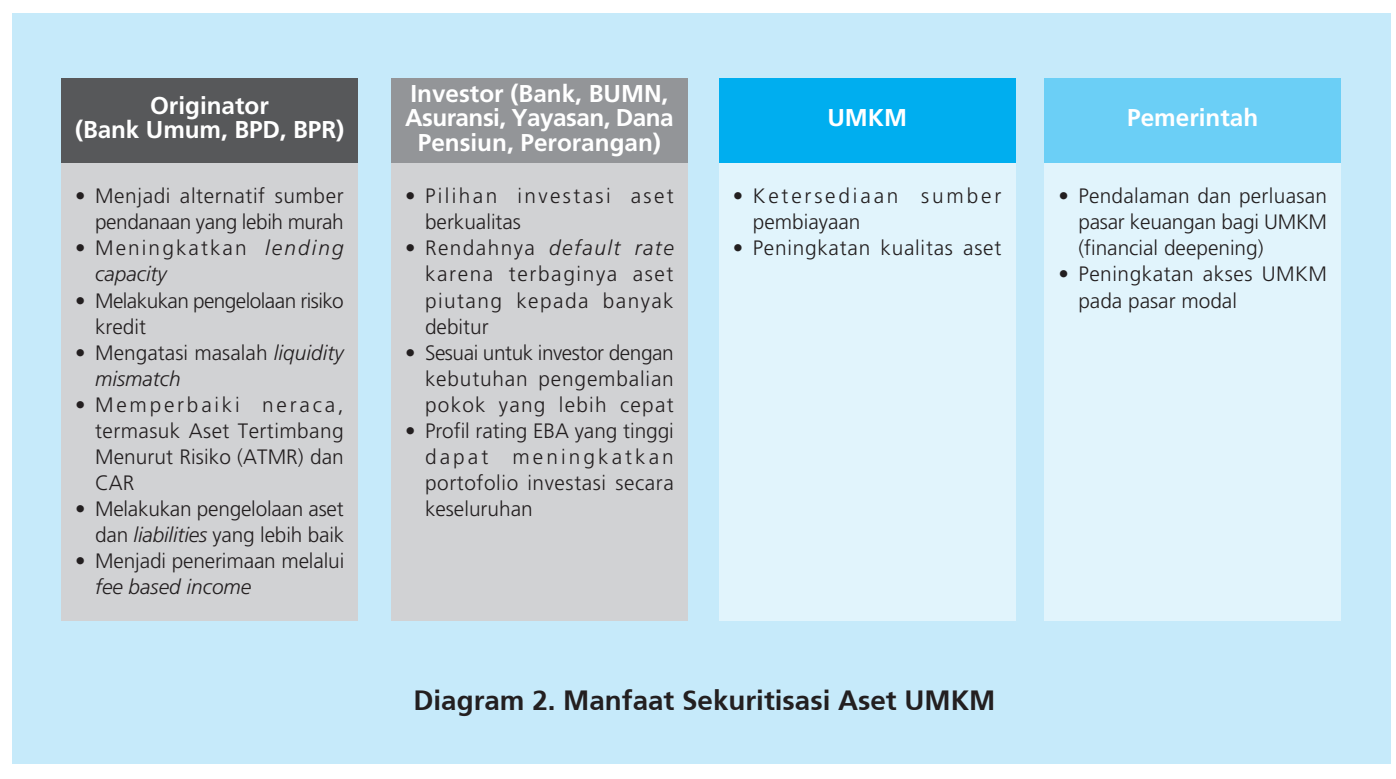

\subsection{Hasil Penelitian Sekuritisasi Aset UMKM Tahun 2011}

Hasil penelitian tahun 2011 menyimpulkan bahwa model sekuritisasi aset UMKM yang direkomendasikan untuk diterapkan di Indonesia adalah model dengan penjaminan (Diagram 3). Penjaminan yang diberikan oleh pemerintah atau lembaga eksternal diharapkan akan meningkatkan minat investor untuk membeli EBA-UMKM karena terdapat unsur jaminan investasi (safe investment). Dengan model ini diharapkan akan mempercepat pengembangan sekuritisasi aset UMKM karena akan mendorong bank-bank untuk berpartisipasi dalam pengembangan sekuritisasi aset UMKM.

Mekanisme ini menjadikan pemerintah harus menyediakan sejumlah dana dalam hal terjadi default pembayaran oleh UMKM serta membentuk lembaga penjamin non-pemerintah, atau lebih memberdayakan lembaga penjamin yang sudah ada, seperti ASKRINDO dan JAMKRINDO. 


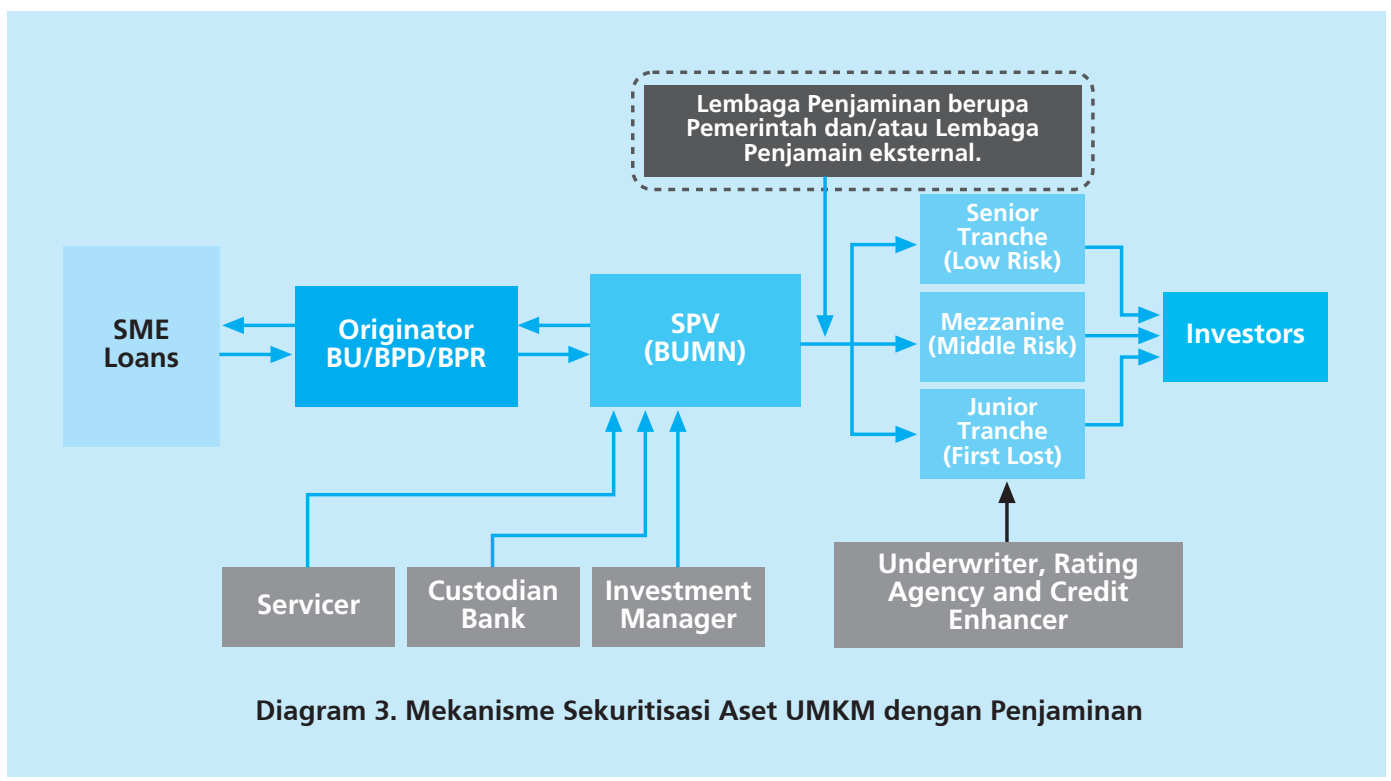

Terdapat beberapa hal yang harus diperhatikan dalam mengimplementasikan model sekuritisasi dengan penjaminan, yaitu:

a. Pemerintah tidak perlu menyediakan dana khusus untuk mengimplementasikan sekuritisasi aset UMKM di Indonesia.

b. Pemerintah dapat menunjuk lembaga penjamin yang ada untuk menjadi penjamin atas aset UMKM yang disekuritisasi sehingga disamping memberdayakan lembaga penjaminan yang ada juga akan mempercepat pengembangan sekuritisasi aset di Indonesia.

c. Pihak-pihak terkait (originator dan investor) akan tertarik untuk melakukan sekuritisasi karena adanya penjaminan, baik secara langsung maupun tidak langsung, oleh pemerintah.

\subsection{Studi empiris}

Berbagai studi empiris telah dilakukan baik oleh akademisi, peneliti maupun praktisi mengenai sekuritisasi. Dari beberapa studi yang pernah dilakukan, umumnya melihat manfaat dan tujuan dari sekuritisasi aset serta hal-hal yang menjadi potensi kendala dalam implementasi sekuritisasi aset sebagaimana dimuat dalam Tabel 2 di bawah ini. 


\section{Tabel 2}

\section{Penelitian Terdahulu Mengenai Sekuritisasi Aset}

No

1. Isnawangsih, Agnes (1998/99) Sekuritisasi Aset di Indonesia

\section{Kesimpulan Hasil Penelitian}

- Dengan mensubstitusikan asetnya bank dapat memperbaiki CAR dan meningkatkan likuiditasnya yang selanjutnya bank dapat memberikan kredit baru.

- Sekuritisasi aset akan memberikan dampak terhadap perkembangan uang beredar (M2). Dampak yang bersifat menambah uang beredar terutama terjadi melalui proses penggandaan uang. Pinjaman dari maupun pembelian aset oleh SPV berpotensi meningkatkan uang beredar melalui membaiknya likuiditas perbankan sehingga bank dapat meningkatkan kredit yang diberikan

2. Park, Jae-Ha et.al (2008) - Developing the Capital Market to Widen and Diversify SME Financing : The Korean Experience

3. Kimborough, Robert T Summary of American Law. Lederman Jass (1996)

- Kesulitan utama dalam meniadakan hambatan pembiayaan di sektor UMKM (SME financing gap) adalah asymmetric information.

- Melalui sistem sharing informasi, lembaga keuangan dapat menyediakan pembiayaan kepada UMKM secara efisien.

Alasan perusahaan memilih mencari dana melalui sekuritisasi aset a.l. :

- Biaya finansial yang sangat rendah. Dengan menggunakan aset yang dimiliki, perusahaan dapat melakukan penjualan efek dengan kualitas kredit yang tinggi dibandingkan dengan nilai perusahaan tersebut.

- Penghematan modal. Apabila dikaitkan dengan pembatasan hutang perusahaan khususnya bagi lembaga keuangan, oleh karena ketentuan pasar modal, maka transaksi dengan pola penjualan asset (true sale) dalam sistem akuntansi dapat mengurangi kebutuhan modal yang besar (higher cost equity).

- Strategi pendanaan yang sesuai. Dengan sekuritisasi efek perusahaan dapat menawarkan pola, jangka waktu dan harga dasar atas efek tersebut.

- Pendapatan. Apabila konsep sekuritisasi adalah penjualan aset (true sale), penerbit atau penjual diperbolehkan untuk mengetahui, sesuai prinsip standard akuntansi (GAAP), keuntungan atau kerugian penjualan aset tersebut, yang diperhitungkan dengan nilai saat ini (present value) dan ekspetasi nilai yang akan datang.

4. Norton, Joseph J, et al. - Alasan investor melakukan investasi pada sekuritisasi aset : International Finance in the - Sebagai alternatif pendanaan jangka panjang 3 - 10 tahun karena KIK EBA 1990s. USA: Blackwell Publisher, 1993. lebih menarik bagi investor dibanding surat utang lain, seperti obligasi dan promes, karena didukung dengan aset yang likuid dan risiko yang relatif kecil.

- Meski originator (penerbit) bangkrut, tagihannya tetap ada. Ini berbeda dari pembeli obligasi atau promes, yang akan kehilangan dananya apabila perusahaan yang bersangkutan bangkrut.

5. Gan, Yingjin Hila dan Christopher Mayer "Agency Conflicts, Asset Subtitution, and Securitization" National Bureau of Economic Research, Cambridge, 2006
Manfaat dan masalah potensial dalam sekuritisasi aset :

- Manfaat dari ABS adalah pengembangan pasar untuk sekuritas, peningkatan likuiditas, dan transparansi.

- Sekuritisasi aset dapat menimbulkan moral hazard dan konflik lembaga yang terkait dengan pemisahan kepemilikan dan pengendalian aset dan konflik kepentingan antara pemegang junior (junior tranche) dan senior (senior tranche). 
Disamping itu, terdapat penelitian oleh Badan Pengawasan Pasar Modal dan Lembaga keuangan (BAPEPAM-LK) bersama dengan Kementerian Keuangan pada tahun 2003 yang meneliti mengenai tingkat pemahaman dari stakeholder terhadap sekuritisasi aset di Indonesia. Temuan dari penelitian ini adalah sebagian besar masyarakat (57,14\% dari jawaban responden) cukup memahami mengenai efek beragun aset. Meski demikian hanya sebagian kecil yang mempunyai pengalaman berkaitan dengan proses sekuritisasi yang dilakukan di luar negeri, yaitu hanya pihak pemeringkat efek dan konsultan hukum. Investor potensial dalam proses sekuritisasi aset meliputi dana pensiun, asuransi, perbankan, LKBB, reksadana, perusahaan besar lainnya, dengan alasan EBA dapat dijadikan sebagai sarana hedging. Dalam penelitian dimaksud juga dikemukakan kendala utama penerbitan EBA yaitu :

a. Kurangnya pemahaman tentang instrumen EBA oleh pelaku dan/atau calon investor.

b. Kewajiban keterbukaan oleh calon originator dikhawatirkan dapat mengarah pada penyalahgunaan informasi.

c. Para pelaku menganggap peraturan yang ada kurang memadai (mulai dari perlakuan akuntansi, perpajakan, teknik perhitungan)

d. Perlunya pedoman yang mengatur akuntansi bagi KIK-EBA, harapan pemberian pembebasan pajak bagi KIK-EBA.

\section{METODOLOGI}

\subsection{Data}

Metode pengumpulan data yang digunakan dalam penelitian ini adalah survei dan focus group discussion (FGD). Teknik yang digunakan untuk survei adalah dengan kuesioner terstruktur dan sampel responden dipilih secara purposive sampling. Survei dilakukan di wilayah Jabodetabek, Bandung, Yogyakarta, Denpasar, Medan, dan Banjarmasin. Adapun responden sampel terdiri dari bank umum, Bank Pembangunan Daerah (BPD), Bank Perkreditan Rakyat (dikategorikan sebagai originator), dana pensiun, asuransi, yayasan (dikategorikan sebagai investor), UMKM, dan lembaga penjamin dengan total 149 responden. Tabel berikut menjelaskan mengenai sebaran responden dan wilayah survei. 


\begin{tabular}{|c|c|c|c|c|c|c|c|}
\hline \multicolumn{8}{|c|}{$\begin{array}{c}\text { Tabel } 3 \\
\text { Sebaran Responden dan Sebaran Wilayah Survei }\end{array}$} \\
\hline \multirow{2}{*}{ Kota } & \multicolumn{3}{|c|}{ Originator } & \multirow{2}{*}{ Investor } & \multirow{2}{*}{ UKM } & \multirow{2}{*}{$\begin{array}{l}\text { Lembaga } \\
\text { Penjamin }\end{array}$} & \multirow{2}{*}{ Tota } \\
\hline & BU & BPD & BPR & & & & \\
\hline Jabodetabek & 30 & 1 & 25 & 25 & 5 & 7 & 93 \\
\hline Bandung & - & 1 & 5 & - & 5 & - & 11 \\
\hline Yogyakarta & - & 1 & 5 & - & 5 & - & 11 \\
\hline Denpasar & - & 1 & 5 & - & 5 & 1 & 12 \\
\hline Medan & - & 1 & 5 & - & 5 & - & 11 \\
\hline Banjarmasin & - & 1 & 5 & - & 5 & - & 11 \\
\hline TOTAL & 30 & 6 & 50 & 25 & 30 & 8 & 149 \\
\hline
\end{tabular}

\subsection{Maxdiff Analysis}

Dalam penelitian ini akan digunakan sstem pengukuran Maxdiff (Maxdiff Analysis). Metode ini bertujuan untuk meningkatkan validitas hasil pengukuran data, terutama data yang berkaitan dengan share of preference atau share of usage jenis-jenis investasi (yakni sekuritisasi aset UMKM vs. jenis investasi lainnya). Berdasarkan pengalaman, mengukur tingkat preferensi atau penggunaan dengan me-ranking data adalah hal yang menyulitkan bagi responden, terutama melakukan rating terhadap data dalam jumlah yang besar ( 5 ke atas). Dengan Maxdiff, proses ini dipermudah dimana responden hanya diminta untuk memilih dari kelompok kecil data hal yang paling dibutuhkan dan yang tidak dibutuhkan.

Pengukuran dan analisis Maxdiff dikembangkan oleh Jourdan Louviere, dimana setiap alternatif pilihan memiliki probabilitas tertentu untuk dipilih

$$
\mathrm{p}_{i}=\frac{\exp (v)_{i}}{\sum_{1}^{k} \exp (v)_{j}}
$$

Dimana / adalah alternatif pilihan sedangkan $k$ adalah jumlah alternatif pilihan.

$$
u_{i}=v_{i}+e_{j}
$$

Alternatif $j$ akan dipilih apabila setelah dibandingkan dengan alternatif lainnya, alternatif tersebut memiliki nilai $p$ paling besar. Pendekatan yang dilakukan untuk mendapatkan dugaan parameter v adalah dengan Maximum Likelihood (ML) atau dengan Hierachical Bayes (HB). Untuk survei ini, pendekatan pendugaan parameter akan didasarkan pada metode HB. Metode ini, menurut Louviere, tidak mensyaratkan jumlah sampel banyak, berbeda dengan pada ML. 
Keuntungan dari pendugaan parameter dengan metode HB adalah hasil dugaannya bersifat individual, sehingga untuk pendugaan suatu segmen cukup "menjumlahkan" data dari setiap individu. Hal ini berbeda dengan metode dimana setiap segmen memerlukan proses pendugaan yang berbeda. Hasil analisis yang dapat diperoleh dari metode Maxdiff adalah kita akan memperoleh dugaan terkait dengan share of demand dari jenis investasi yang diminati investor.

\section{HASIL DAN ANALISIS}

\subsection{Originator}

Hasil survei menunjukkan bahwa pemahaman originator terhadap istilah sekuritisasi masih tidak sama. Bank Umum dan BPD memiliki tingkat awareness yang lebih tinggi daripada BPR. Hanya sebesar 25\% BPR pernah mendengar istilah sekuritisasi. Meski demikian, secara keseluruhan pemahaman originator terhadap sekuritisasi masih kurang memadai.

Walaupun konsep EBA-UMKM dianggap cukup menarik oleh originator, terdapat beberapa faktor yang menyebabkan minat originator untuk menjual piutang kredit UMKM dalam bentuk EBA-UMKM rendah. Bagi originator, kemampuan yang terbatas dalam menyalurkan kredit terhadap UMKM bukanlah disebabkan keterbatasan dana mengingat dalam beberapa tahun terakhir ini bank umum serta BPD pada umumnya mengalami kelebihan likuiditas. Hambatan untuk memperbesar penyaluran kredit kepada UMKM lebih dikarenakan kondisi persaingan yang cukup ketat pada besaran pasar yang kurang berkembang, mengingat ceruk pasar UMKM yang laik bank (bankable) juga tidak banyak berubah dari waktu ke waktu, dengan strategi akuisisi cukup gencar dilakukan oleh bank yang mencakup tawaran take-over credit dengan bunga yang murah. Sementara itu, untuk penyaluran kredit terhadap UMKM diperlukan tenaga kerja yang cukup banyak dan teknologi pendukung yang memadai. Hal itu karena kredit UMKM bersifat big volume dan low value, serta nasabah UMKM membutuhkan pendampingan yang memadai agar tingkat NPL bisa terjaga. Walaupun konsep EBA-UMKM dianggap cukup menarik, kondisi ini yang menyebabkan minat originator untuk menjual piutang kredit UMKM dalam bentuk EBA-UMKM tetap rendah.

Kekhawatiran terbesar para originator dalam mengimplementasikan EBA-UMKM adalah risiko gagal dalam pengelolaan. Penyaluran kredit kepada UMKM harus disertai dengan pengamatan dan pembinaan yang cukup baik, yaitu berupa kunjungan rutin ataupun konsultasi. Sementara itu, dengan dijualnya piutang UMKM tersebut, fokus perhatian pasti akan lebih ditujukan kepada nasabah-nasabah baru yang didanai dari hasil penjualan aset tersebut. Hal ini menimbulkan kekhawatiran bahwa mereka tidak akan mampu menjamin atau mempertahankan performance dari piutang yang dijual. Hal ini juga terkait erat dengan kekhawatiran mengenai ketidaksiapan SDM yang dimiliki sehingga UMKM mengalami kesulitan dalam penanganan administrasi yang bersifat khusus. 
Kekhawatiran lain adalah terjadinya risiko apabila UMKM melakukan pembayaran lebih awal sementara investor telah memilih sistem pembayaran arus kas tetap (pay through), terlebih karena mengingat bahwa praktik take-over kredit UMKM di kalangan perbankan cukup tinggi. Terkait dengan hal ini, dikhawatirkan pula ada pemberian beban tambahan pekerjaan administrasi karena harus menggantikan piutang UMKM yang telah disekuritisasi tersebut dengan piutang lainnya.

Masalah ketidakpastian hukum atau aturan juga menjadi kekhawatiran lainnya, terlebih dengan kriteria pemeringkatan (rating) serta kinerja dari lembaga yang menangani pemeringkatan itu sendiri. Oleh sebab itu, para originator umumnya beranggapan bahwa sekuritisasi piutang UMKM tidak dapat dilakukan semudah sekuritisasi kredit perumahan. Ceruk pasar untuk kredit perumahan berkembang sepadan dengan pertumbuhan penduduk. Sementara itu, ceruk pasar kredit UMKM sesungguhnya berkembang sangat lambat karena pertumbuhan UMKM yang laik bank (bankable) yang lambat. Apabila sekuritisasi harus dilakukan, sebagian besar responden (59\%) hanya bersedia untuk melepaskan piutang dengan kualitas yang buruk/sangat buruk. Bahkan, bagi mereka yang menyatakan bersedia untuk melepaskan piutang UMKM dengan kualitas baik/sangat baik pun, 33\% di antaranya menyatakan bahwa sesungguhnya akan merasa sayang dalam melepaskan piutang tersebut untuk dilakukan sekuritisasi. Hal ini karena mengingat keuntungan yang diperoleh dianggap tidak sepadan dengan upaya yang telah dilakukan dan risiko yang harus ditanggung dalam menyalurkan kredit UMKM tersebut. Oleh karena itu, mayoritas responden (65\%) menolak untuk membeli bagian EBA kelas yang paling bawah. Seluruh kekhawatiran tersebut diperburuk oleh pemahaman kurang jelas akan sekuritisasi EBA-UMKM akibat sosialisasi yang masih kurang memadai.

Untuk implementasi EBA-UMKM, 21\% originator menyatakan bahwa sekuritisasi aset tersebut layak untuk dijalankan segera dalam jangka waktu satu tahun ke depan. Sebagian besar yang menyatakan demikian adalah BPR (75\%), yang justru pada umumnya memiliki pengetahuan yang sangat kurang memadai akan sekuritisasi EBA-UMKM. Sementara itu, 41\% responden beranggapan bahwa sekuritisasi EBA-UMKM hanya layak untuk dilakukan pada 2-5 tahun ke depan, dan sebanyak 23\% responden menyatakan bahwa sekuritisasi EBA-UMKM layak dilakukan setelah lebih dari 5 tahun, dan 16\% responden menyatakan tidak tahu pasti.

\subsection{Investor}

Terdapat beragam bentuk investasi yang dilakukan investor. Setiap investor umumnya mengalokasikan dana investasi dalam 2 s.d. 4 bentuk investasi dengan alokasi dana investasi maksimal 25\%. Tercatat proporsi alokasi dana investasi tahun 2011 sebagian besar dalam bentuk obligasi (60\%), Sertifikat Bank Indonesia (SBI) (52\%, yang mayoritas adalah bank umum), dan deposito (52\%). Pada ketiga bentuk investasi ini terdapat responden yang menginvestasikan lebih dari 75\% dari dana investasi yang dimilikinya. 
Dalam menentukan produk investasi yang akan dipilih, hampir seluruh responden berfokus pada masalah yield/return (96\%) serta tingkat risiko (92\%), diikuti oleh tingkat likuiditas (72\%). Khusus bagi responden investor dari kalangan perbankan, tingkat likuiditas dianggap merupakan faktor yang sama pentingnya dengan yield serta tingkat risiko. Sementara itu, suku bunga yang memengaruhi tingkat pengembalian minimal keputusan investasi meliputi suku bunga deposito (40\%), SBI (28\%), dan kupon obligasi (12\%).

Sebagian besar investor (72\%) menyatakan mengetahui istilah sekuritisasi aset meski pemahaman terhadap esensi produk yang sesungguhnya cenderung masih belum memadai. Mayoritas responden menyatakan berminat/sangat berminat untuk berinvestasi dalam produk EBA-UMKM dengan besaran investasi setara dengan 10\%-15\% dari total dana investasi yang dimiliki apabila tingkat pengembalian produk EBA-UMKM adalah $13 \%$ atau minimal $11 \%$. Dengan tingkat pengembalian tersebut, produk EBA-UMKM akan cenderung dijadikan sebagai pilihan kedua (19\% responden) setelah SBI (21\% responden). Tingginya ekspektasi atas tingkat pengembalian EBA-UMKM dikarenakan produk EBA-UMKM dianggap kurang/tidak likuid akibat belum terbentuknya pasar sekunder.

Hasil survei menunjukkan bahwa originator EBA-UMKM yang lebih disukai adalah bank umum-BUMN (92\%) serta bank umum-swasta nasional (68\%). Tiga kriteria utama yang diharapkan dari bank sebagai originator/issuer adalah bank harus memiliki reputasi baik atau merupakan bank yang benar-benar sehat (56\%), memiliki aset cukup besar (28\%), dan berpengalaman dalam penyaluran kredit UMKM (28\%). Sektor perdagangan merupakan sektor yang diminati untuk produk EBA-UMKM (52\%), diikuti dengan sektor industri pengolahan (36\%). Dalam hal ini, pemerintah diharapkan dapat bertindak sebagai penjamin EBA-UMKM.

Sebagian besar investor (56\%) berkeyakinan bahwa EBA-UMKM akan dapat berjalan dengan baik apabila diimplementasikan dalam jangka menengah, yaitu 3-4 tahun yang akan datang. Sementara sebagian investor lainnya (24\%) pesimis terhadap keberhasilan implementasi EBA-UMKM, dengan alasan mempersiapkan pasar serta lembaga-lembaga penunjang bukanlah hal yang mudah dan diperlukan kerja keras serta waktu yang sangat lama. Terdapat beberapa faktor penting yang harus diperhatikan pada saat mengimplementasikan EBA-UMKM, yaitu: (i) kejelasan peraturan tentang struktur transaksi dan pihak-pihak yang terkait dalam transaksi EBA (52\%); (ii) dukungan pemerintah melalui undang-undang (20\%), (iii) eksekusi jaminan yang jelas yang sepenuhnya dilindungi oleh undang-undang (16\%); (iv) keberadaan lembaga penjamin yang dapat dipercaya (16\%); (v) disosialisasikannya peraturan dengan baik (12\%); terpenuhinya regulasi yang legal (8\%), dan (vi) dukungan regulator seperti BI dan Bapepam LK.

\subsection{Lembaga Penjamin atau Asuransi}

Lembaga penjamin atau perusahaan asuransi yang memberikan penjaminan atas kredit tampaknya masih belum cukup berkembang di Indonesia. Hal ini terlihat dari kesulitan yang 
dihadapi untuk mendapatkan target responden segmen lembaga penjamin dan perusahaan lembaga penjamin kredit, yang sebagian besar merupakan milik pemerintah pusat atau pemerintah daerah. Meskipun demikian, terdapat indikasi adanya pertumbuhan bisnis dari perusahaan lembaga penjamin yang tercermin dari pertumbuhan jumlah karyawan permanen yang terserap dalam industri ini yang mengiringi penurunan jumlah karyawan kontrak.

Pemerintah tampaknya mulai memberi perhatian pada perkembangan lembaga penjamin karena lembaga penjamin milik pemerintah pusat dan daerah ternyata telah melakukan penambahan modal. Pada tahun 2011, terdapat penambahan modal lembaga penjamin antara 5\% s.d. 35\%. Penjaminan terhadap kredit UMKM bukan merupakan hal yang baru bagi perusahaan lembaga penjamin. Namun, terdapat indikasi bahwa kredit UMKM dinilai lebih berisiko daripada kredit koperasi dan KPR. Hal ini tercermin dari biaya (fee) yang dikenakan oleh lembaga penjamin (lebih tinggi) serta besaran penjaminan yang diberikan (lebih rendah). Tingkat risiko serta prospek usaha pada masa mendatang adalah hal utama yang dipertimbangkan dalam memberikan penjaminan untuk sebuah produk investasi.

Untuk penjaminan/asuransi bagi kredit koperasi, tercatat proporsi produk penjaminan bagi kredit koperasi dari total keseluruhan bisnis berkisar dari 5\% s.d. 87\%. Biaya (fee) pembebanan berkisar antara 1,5\% s.d. 3,8\%. Jaminan yang ditanggung antara 75\% s.d. 100\% atas nilai kredit. Sementara untuk produk lain termasuk kredit UMKM, proporsi produk penjaminan bagi kredit UMKM berkisar dari 5\% s.d. 100\% dari keseluruhan nilai bisnis. Biaya (fee) pembebanan adalah sama yaitu berkisar antara 1,5\% s.d. 3,8\%. Jaminan yang ditanggung antara 70\% s.d. $100 \%$ atas nilai kredit.

Dalam memberikan penjaminan, umumnya dilakukan praktik reinsurance atau penjaminan kembali pada perusahaan lembaga penjamin/asuransi lainnya. Hambatan-hambatan yang dihadapi lembaga penjamin dalam menjalankan bisnis sehari-hari dan dalam melakukan perluasan jangkauan meliputi keterbatasan permodalan dan SDM, hambatan ketentuan, seperti ketentuan $\mathrm{BI}$ yang mewajibkan agar sertifikat penjamin non-BUMN harus diperingkat, persaingan antar lembaga penjamin, kualitas UMKM yang belum memadai, dll.

Sebagian besar perusahan lembaga penjamin EBA-UMKM kurang mengenal produk EBA-UMKM, dan tingkat risiko produk tersebut dikategorikan sedang hingga tinggi. Penilaian tersebut dilandasi oleh anggapan bahwa pelaku UMKM umumnya melakukan pengelolaan usaha secara tradisional dengan manajemen usaha yang tidak teratur, memiliki rekam jejak (track record) yang sulit untuk diketahui, berlokasi pada tempat yang rentan mengalami kebakaran, dan dipersepsikan memiliki NPL (non-performing loan) tinggi.

Meskipun demikian, sebagian besar lembaga penjamin berminat/sangat berminat untuk menjadi penjamin bagi produk EBA-UMKM, khususnya untuk produk EBA-UMKM dari sektor perdagangan yang diterbitkan/dijual oleh bank umum-BUMN dengan biaya (fee) sebesar 2,5\% s.d. 5\%, disusul dengan sektor keuangan, real estate dan jasa perusahaan, konstruksi, industri 
pengolahan dan pariwisata namun dengan biaya (fee) yang lebih besar dari $1 \%$ dan dengan rata-rata coverage penjaminan sebesar maskimal $73.8 \%$.

Hampir seluruh responden lebih berminat untuk menjadi penjamin bagi produk EBAUMKM yang diterbitkan/dijual oleh bank umum-BUMN mengingat produk tersebut dinilai memiliki tingkat risiko yang lebih rendah daripada produk EBA yang dijual oleh bank umumbukan BUMN. Hal ini didasari oleh keyakinan bahwa bank umum-BUMN lebih berpengalaman dalam mengelola kredit UMKM serta memiliki aset yang cukup banyak dan merupakan bank pemerintah yang pasti terjamin kesehatan permodalannya.

Lembaga pemeringkat yang disukai sebagai penjamin adalah milik pemerintah (38\%) atau Pefindo (PT Pemeringkat Efek Indonesia) (38\%). Faktor-faktor yang dipandang penting untuk diperhatikan dalam melakukan pemeringkatan adalah jenis usaha UMKM, NPL yang rendah, agunan, kredibilitas sektor usaha dan kualitas kepemilikan usaha serta pertumbuhan labanya.

Optimisme perusahaan penjaminan terhadap program EBA-UMKM lebih tinggi daripada optimisme kalangan investor. Sebagian besar lembaga penjamin cukup optimis bahwa EBAUMKM dapat diimplementasikan dalam 1-2 tahun ke depan. Namun, hanya 13\% dari responden lembaga penjamin yang mengetahui dengan baik aturan mengenai sekuritisasi, sementara sisanya (87\%) tidak mengetahui aturan mengenai sekuritisasi aset.

\subsection{UMKM}

Perkembangan bisnis UMKM selama ini cukup baik. Selama periode 2010-2011, seluruh UMKM memiliki omzet usaha yang cukup stabil dan cenderung meningkat pada tahun 2012. Sebagian di antaranya mengalami peningkatan laba dari tahun ke tahun. Meskipun demikian, masih cukup banyak UMKM kategori kecil menengah (dengan omzet usaha minimal Rp300 juta/ tahun) yang tidak memiliki status badan hukum dan hanya berstatus milik perorangan (30\%) dan dalam beroperasi hanya mengandalkan Surat Izin Usaha dari kelurahan. Bahkan, sebagian besar (57\%) masih menggunakan pencatatan keuangan secara manual dalam pengelolaan keuangannya.

Kendala utama yang dihadapi UMKM selama ini dalam mengelola usahanya adalah permodalan (63\%), pemasaran (30\%) dan SDM (27\%). Keterbatasan UMKM yang umumnya tidak memiliki badan hukum serta perizinan yang memadai serta administrasi pencatatan keuangan yang masih sederhana menjadikan sebagian UMKM hanya mampu mengakses kredit mikro dan supermikro dari perbankan. Kondisi ini yang menjadikan apabila terdapat keperluan tambahan dana, sebagian besar UMKM mengandalkan modal sendiri atau diperoleh dari keluarga, teman, pelepas uang, serta pinjaman dari lembaga keuangan non-bank. Hasil survei menunjukkan baru 13\% UMKM yang memiliki laporan keuangan yang telah diaudit oleh akuntan publik. 
Pinjaman yang diperoleh dari bank umumnya digunakan untuk modal kerja (93\%) dan investasi (33\%). Namun, ada pula yang menggunakannya untuk kesejahteraan karyawan (3\%). Pinjaman tersebut umumnya berjangka waktu menengah (1 s.d. 3 tahun). Bank yang paling banyak diakses adalah BRI (27\%), Mandiri (17\%) serta BPR (13\%) dengan tingkat suku bunga umum yang berkisar antara 12\%-14\%. UMKM umumnya beranggapan bahwa tingkat suku bunga yang wajar adalah 10\%-12\%, atau 2\% lebih rendah daripada suku bunga yang berjalan selama ini.

Sebagian besar UMKM (83\%) menyatakan tidak pernah mengalami masalah untuk memenuhi kewajiban pengembalian atas pinjaman yang diperoleh dari bank. Sedangkan sisanya (17\%) menyatakan terkadang mengalami hambatan yang dikarenakan keterlambatan pembayaran yang dilakukan oleh pelanggan, jumlah pelanggan yang menurun, cuaca yang tidak menentu sehingga menghambat proses produksi, bunga yang dirasakan terlalu membebani, serta terhambatnya kegiatan usaha akibat bencana gempa (seperti yang terjadi di Yogyakarta).

Bank cukup aktif dalam memanfaatkan pelanggan yang sudah ada untuk penyaluran kredit yang tercermin dari sebagian besar UMKM (77\%) sering mendapatkan tawaran penambahan pinjaman bank dalam 3 tahun terakhir. Hampir seluruh responden (93\%) juga pernah ditawari untuk mendapatkan kredit baru.

\subsection{Analisis SWOT dan Analisis Gap}

Dalam penelitian ini dipandang perlu untuk melakukan Analisis SWOT dan Analisis Gap dalam rangka mencapai tujuan penelitian. Analisis SWOT secara sederhana dipahami sebagai instrumen atau perangkat yang didesain dan digunakan sebagai langkah awal dalam proses pembuatan keputusan dengan melihat permasalahan dari empat sisi yang berbeda, yaitu memaksimalkan faktor kekuatan, memanfaatkan peluang yang ada, meminimalisir kelemahan yang ada, serta menekan dampak ancaman yang timbul dan harus dihadapi. Gambar di bawah mengilustrasikan analisis SWOT dari pemanfaatan sekuritisasi aset sebagai alternatif pembiayaan bagi UMKM dalam rangka mendorong sektor riil. 


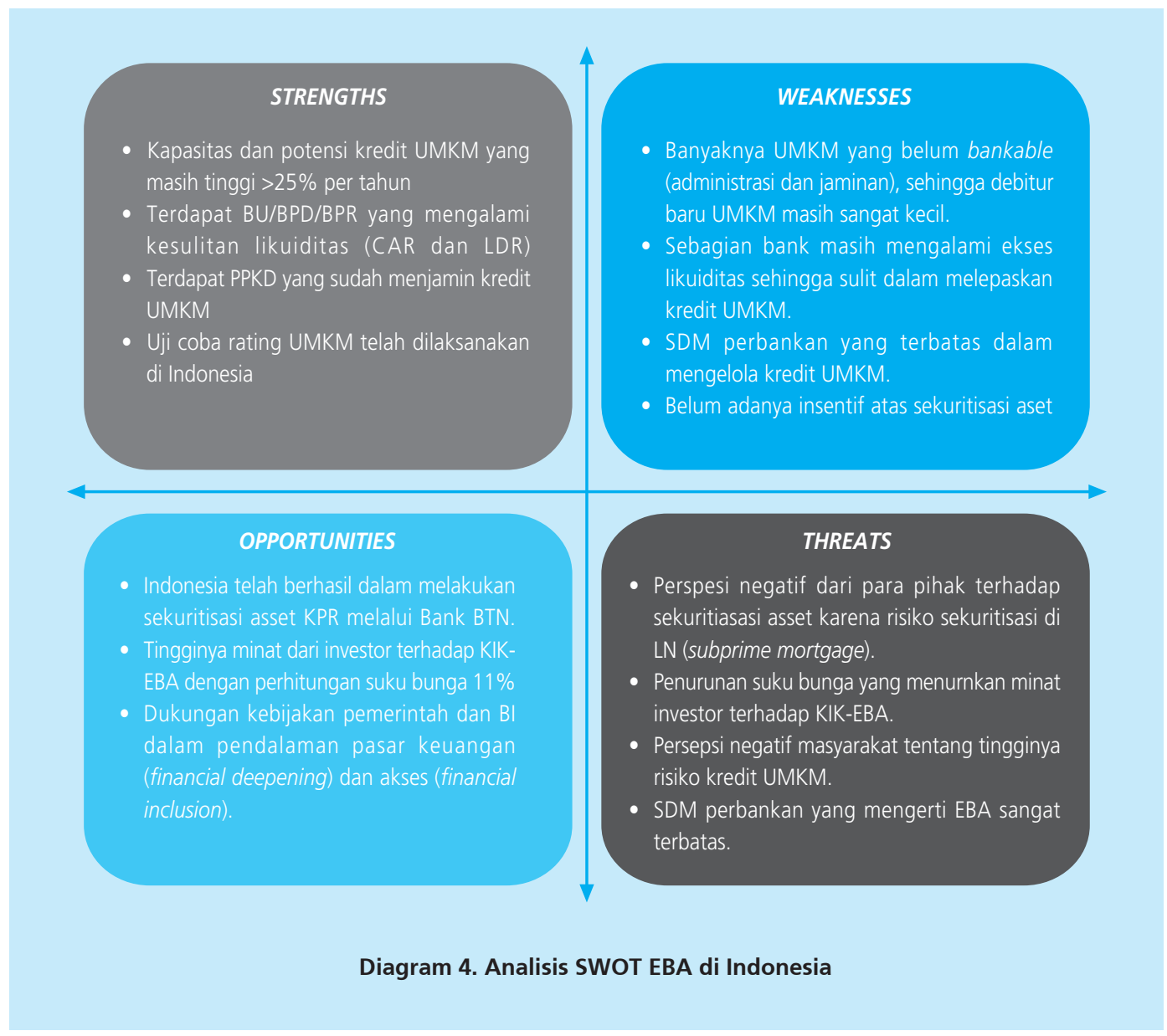

Analisis Gap dimaksudkan untuk melihat kondisi saat ini dan kondisi ideal dalam suatu situasi. Dalam businessdirectory.com disebutkan bahwa gap analysis merupakan suatu teknik dimana bisnis menggunakannya untuk menentukan langkah apa yang harus dilakukan secara bertahap untuk bergeser dari level saat ini ke level yang diinginkan atau level berikutnya. Gap analysis juga sering disebut dengan need-gap analysis, needs analysis, dan needs assessment. Untuk penelitian ini, analisis gap digunakan untuk melihat situasi saat ini dari para pihak yang terlibat dalam sekuritisasi aset, termasuk kebijakan dari pemerintah, kemudian dibandingkan dengan kondisi yang diharapkan apabila sekuritisasi aset UMKM diimplementasikan. Hal ini dapat dilihat pada Diagram 5. 


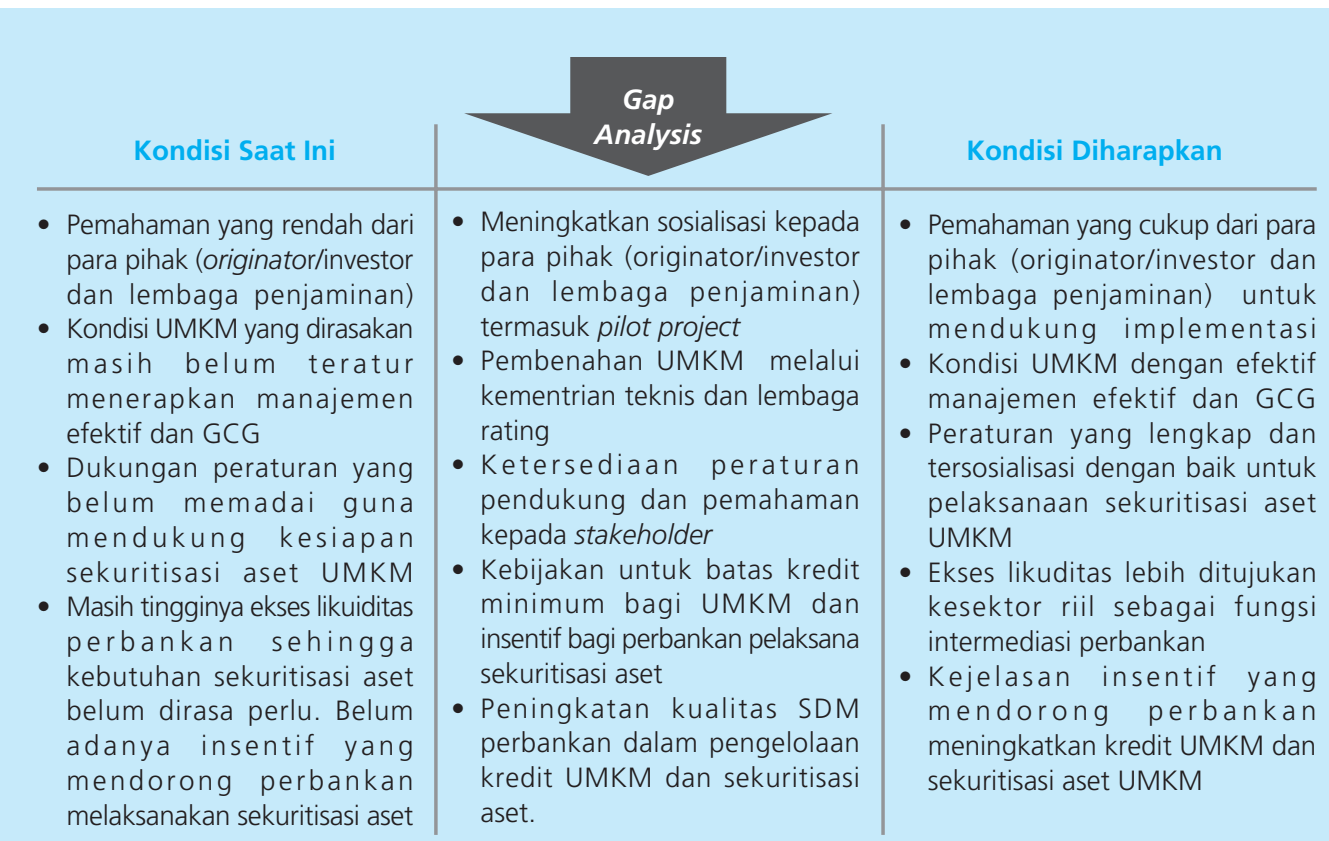

Diagram 5. Analisis Gap Implementasi EBA-UMKM di Indonesia

Dari gambar di atas, tampak bahwa untuk menutup kesenjangan yang terjadi antara kondisi saat ini dengan yang diharapkan, maka terdapat lima hal yang harus dilakukan agar EBA-UMKM dapat diimplementasikan di Indonesia, yaitu :

1. Dalam rangka memberikan pemahaman yang cukup kepada pihak-pihak yang terlibat yang selama ini dirasakan sangat kurang, maka dipandang perlu untuk meningkatkan sosialisasi kepada pihak-pihak terkait, yaitu : originator, investor, dan lembaga penjamin.

2. Dipandang perlu melakukan pembenahan di sisi UMKM melalui kementerian teknis dan lembaga pemeringkat agar tercipta kondisi UMKM dengan manajemen efektif dan good corporate governance (GCG).

3. Menyediakan peraturan pendukung dan memberikan pemahaman kepada stakeholders agar supaya peraturan yang lengkap tersosialisasi dengan baik dalam rangka pelaksanaan sekuritisasi aset UMKM.

4. Memberikan berbagai insentif kepada perbankan pelaksana sekuritisasi (originator) agar implementasi sekuritiasi asset UMKM dapat berjalan mengingat saat ini perbankan belum tertarik untuk melakukan sekuritisasi yang dikarenakan oleh masih tingginya likuiditas bank. 
5. Meningkatkan kualitas SDM perbankan dalam pengelolaan kredit UMKM dan sekuritisasi aset agar supaya kredit UMKM dapat disekuritiasi.

\section{KESIMPULAN}

Dengan memperbesar jumlah dan cakupan responden, penelitian (lanjutan) tahun 2012 ini lebih memfokuskan kepada pihak-pihak yang akan menerbitkan sekuritisasi. Penelitian ini menyimpulkan bahwa berdasarkan hasil survei dan FGD, implementasi sekuritisasi aset sebagai alternatif pembiayaan bagi sektor riil dan UMKM kiranya belum dapat dilakukan dalam waktu dekat. Beberapa alasan yang melatarbelakangi kesimpulan tersebut antara lain:

1. Pemahaman pelaku usaha terhadap sekuritisasi aset UMKM di Indonesia belum maksimal.

2. Sebagian besar bank masih belum berminat menjadi kreditur asal (originator) yang dikarenakan likuiditas perbankan masih cukup tinggi, LDR (Loan to Deposit Ratio) perbankan masih rendah, relatif sulitnya mencari nasabah baru UMKM, serta sosialisasi mengenai konsep sekuritisasi aset UMKM yang dirasakan masih kurang. Kondisi yang sebaliknya justru terjadi dimana hasil survei dan FGD menunjukkan bahwa sebagian besar bank cenderung ingin menjadi investor daripada menjadi originator.

3. Masih diperlukan landasan hukum yang kuat berupa penyusunan ketentuan sekuritisasi aset UMKM, di samping ketentuan mengenai KIK-EBA yang sudah ada saat ini.

4. Perlu dipertimbangkan insentif bagi perbankan apabila akan berperan sebagai originator.

5. Skema sekuritisasi aset UMKM harus didukung oleh lembaga pemeringkat yang bertugas melakukan pemeringkatan UMKM.

6. Untuk mengimplementasikan model yang sesuai dengan kondisi di Indonesia, masih diperlukan penguatan koordinasi dengan instansi terkait.

7. Diperlukan pembenahan atau pembinaan UMKM dari sisi manajemen dan tata laksana dalam rangka meningkatkan kinerja Good Corporate Governor. 


\section{DAFTAR PUSTAKA}

A Research Bulletin of the Centre for Real Estate Studies (CRES). (2004). Department of Real Estate. NUS, July 2004 Volume 4, No. 2.

Cagamas. (2007). Cagamas Launches Securitisation of SME Loans. Kuala Lumpur. Retrieved from http://www.cagamas.com.my/sites/default/files/Press/files/pr_22may07.pdf

Cousseran, O. \& Rahmouni, I. (2005). The CDO Market Functioning and Implications in Terms of Financial Stability. Banque de France. Financial Stability Review, no.6 June 2005.

Departemen Keuangan RI dan Badan Pengawas Pasar Modal. (2003). Studi Tentang Perdagangan Efek Beragun Aset, Tim Studi Perdagangan Efek Beragun Aset Departemen Keuangan dan Bapepam.

Gan, Yingjin Hila dan Christopher Mayer. (2006). Agency Conflicts, Asset Subtitution, and Securitization. NBER Working Paper No. 12359.

Gaon, Stav. (2007). Essays in Securitization. PhD Tesis. Columbia University.

Hirata, H., \& Shimizu, T. (2004). Purchase of SME-related ABS by the Bank of Japan (Updated): Monetary Policy and SME Fianancing in Japan. Bank of Japan Working Paper.

Isnawangsih, Agnes. (1998/99). Sekuritisasi Aset di Indonesia, Bank Indonesia.

Jae-Ha Park, et al. (2008). Developing the Capital Market to Widen and Diversity SME Financing: The Korean Experience. Korea Institute of Finance.

Kimborough, Robert T. (1996). Summary of American Law. Lederman Jass

European Commission. (2007). SME Securitisation: Final Report, Roundtable between Bankers and SMEs. Enterprise Publication.

Ketkar, Sushas dan Ratha, Dilip. (2004-2005). Recent Advances in Future-Flow Securitization. The Financier Vol. 11/12.

Reserve Bank of India. (1999). Securitizations in China-Characteristics and Difficulties dalam Report of the In-house Working Group On Asset Securitisation. Retrieved from https:// www.rbi.org.in/scripts/PublicationReportDetails.aspx?FromDate $=12 / 29 / 99 \& S E C I D=21 \& S$ UBSECID=0

Santoso, Wijoyo et.al. (2011). Pemanfaatan Sekuritisasi Aset dalam Rangka Mendorong Sektor Riil: Alternatif Pembiayaan UMKM. Working Paper PRES, Bank Indonesia. 
Acharya, Viral V., et al. (2010). Securitization without Risk Transfer. National Bureau of Economic Research. NBER Working paper, no. 15730.

Chlupacek, Philip. (2009). European SME Financing and Structured Finance. Thesis. University of Wien.

Norton, Joseph J, et al. (1993). International Finance in the 1990s. USA: Blackwell Publisher. 